\title{
Market Economy \& Economics of Competition Law Exhibits Juxtaposition of a Craftsman Tribe: The Mahali.
}

\author{
Dr. Suparna Sanyal Mukherjee ${ }^{1}$ \\ ${ }^{1}$ Head PhD Cell \& Academic Coordinator, HOD Social Science, \\ Seacom Skills University, Bolpur, Santiniketan, Birbhum, West Bengal.
}

\begin{abstract}
In economics competition is a condition where different economic firms seek to obtain a share of a limited good by varying the elements of the market orientation regarding price, product, promotion and place. In economy it's thought that, competition causes commercial firms to develop new products, services and technologies, which would give consumers greater selection and better products. Early economic research focused on the difference between priceand non-price-based competitions, while later economic theory has focused on the many-seller limit of general equilibrium. Competition law is essentially concerned with the study of market economy. There are different communities who impinged in the same market economy of crafts as the Mahali were/are continuing. Non availability of raw materials, soaring price of commodities, the legal embargo all combined hindered the present economic situation of the Mahali. The Mahali a craftsman tribe, who's socio-economic, socio-cultural and techno-economic life were/are based on minor forest produce bamboo being the principal ingredient of their traditional occupation, generation wise, but presently they are unable to do the same. This sequel is aimed to find their present socio-economic conditions and sustenance of livelihood under the implemented Forest Act, Policies along with economics of competition law orientation in the form of a market economy and its consequences on the forest dwelling craftsman tribe the Mahali, exhibits juxtaposition of their ware in the market economy and competition thereof, enhance development in the economic pursuit with protection of crafts from imperil.
\end{abstract}

Key Words:- Competition, Craft, Economy, Forest, Law, Market, Policy, Tribe.

\section{INTRODUCTION}

In economics competition is a condition where different economic firms seek to obtain a share of a limited good by varying the elements of the market orientation regarding price, product, promotion and place. In economy it's thought that, competition causes commercial firms to develop new products, services and technologies, which would give consumers greater selection and better products. The greater selection typically causes lower prices for the products, compared to what the price would be if there was no competition known as monopoly or little competition marked as oligopoly. Early economic research focused on the difference between price- and non-price-based competitions, while later economic theory has focused on the many-seller limit of general equilibrium. There are several scientists who pursued their work on the concerned matter of which few are mentionable here. Jeffery Sachs in 2011 describe in his book The Price of Civilization about the reawakening American virtue and prosperity. He also emphasized upon in Poland's jump to the Market Economy, Jeffrey Sachs provides an insider's analysis of the political events and economic strategy behind the country's swift transition to capitalism and democracy. Akriti Gupta also worked on competition law. She described in her article that the competition law in India draws a complete picture of the competition law the governs the domestic and international market of the Indian economy. It brings out the necessity to regulate the market. D.N.Baskey and Ashim Adhikary also worked on Mahali economy and their market orientation.

Competition law is essentially concerned with the study of market economy, the objective being to ensure that there is competition between the suppliers in any market and that the competition benefits consumers. A market economy is an economic system in which individuals own most of the resources - land, labor, and capital - and control their use through voluntary decisions made in the marketplace. In this type of economy depends upon two forces - self-interest and competition which play a very important role in the issue of market economy system. There are forty tribal groups spread over West Bengal, the Mahali, who is one of them residing deep inside the forest and its fringe of Paschim Medinipur. The Mahali, who engage themselves in various crafts are essentially basket weavers, making baskets from Bamboo and Atar, a typical creeper plant (very rare now), so forest is/was their main source of livelihood sustenance. 


\section{International Advanced Research Journal in Science, Engineering and Technology}

Vol. 8, Issue 6, June 2021

\section{DOI: 10.17148/IARJSET.2021.86107}

The Mahali a craftsman tribe, who's socio-economic, socio-cultural and techno-economic life were/are based on minor forest produce bamboo being the principal ingredient of their traditional occupation, generation wise, but presently they are unable to do so, for various reasons.

Nonetheless, there is a gap between of the assumptions of such theories of law, realities and practices remains pervasive. The Mahali are still in a dismal situation and facing immense challenges, competitions from the caste peasants and producers of the same utilities, in the social context and market economy, while competition law directly involved in such economic pursuits. This sequel is aimed to find their present socio-economic conditions and sustenance of livelihood under the implemented Forest Act, Policies and Five-Year Plans along with economics of competition law orientation in the form of a market economy and its consequences on the forest dwelling craftsman tribe the Mahali, exhibits juxtaposition of their ware in the market economy and competition thereof, enhance development in the economic pursuit with protection of crafts from imperil.

\section{EXPERIMENTAL METHODS}

Indian Forest Act 1865 as amended 1878 and finally enacted in 1927 put an embargo in entry to the forest and exit thereof, thus their economy was totally hit. They lost their age-old rights over the forest; thereby these tribes were compelled to do away with traditional occupation and find an alternative method for sustaining livelihood. The dismal situation prevailed since the inception of the said Act which is still in force pushing these tribes in utter dismay. 1894, 1952 and1988 Forest Policies, five-year plans which provided few concessions to these people which was/are not adequate enough. Post-Independence planning and rehabilitation programmes tailored for them have not reached them properly. The dismal situation continues even today, making them persona-non-grata, but life goes on. The chosen tribe was compelled to adopt change in economic pursuit, for which the inception of the Indian Forest Act is to be held responsible. Nonetheless, there is a gap between of the assumptions of such theories of law, realities and practices remains pervasive. The Mahali are still in a dismal situation and facing immense challenges, competitions from the caste peasants and producers of the same utilities, in the social context and market economy, while competition law directly involved in such economic pursuits. The Mahali a craftsman tribe, who's socio-economic, socio-cultural and techno-economic life were/are based on minor forest produce bamboo being the principal ingredient of their traditional occupation, generation wise, but presently they are unable to do so, for various reasons like scarcity of raw materials, entering caste people in the same occupation, increment of prices, though the bamboo wares has marketability, are ecofriendly and biodegradable, but ignorance, lack of awareness, illiteracy and low knowledge of implementing science and technology refrain their products from approval in the recent market economy which enhance competition in the market economy. The kuendisole village is situated in the fringe of the Jhargram Forest Range and Forest Division of Paschim Medinipur District, West Bengal. Only the Mahali tribe is resided in the village with caste peasants. Twentyfive households are surviving along with general caste people. They maintain their livelihood sustenance by way of craftsmanship also collect non-timber minor forest products for home consumption and selling it for the income. Bamboo is their only raw materials which they collect from forest. Though the collection was free of cost but inaccessibility in the forest and for the implementation of the Forest Act they can't acquire it from the forest rather they have to buy it from the market and manufacture the products for selling in the market. Hence market economy is very uncertain to them to access.

\section{RESULTS AND DISCUSSION}

Table 1 Population Distribution of the Study Village

\begin{tabular}{|c|c|c|c|c|c|c|c|c|c|c|c|c|c|c|}
\hline \multirow{3}{*}{$\begin{array}{l}\text { SN } \\
\\
01 \\
\end{array}$} & \multirow{3}{*}{$\begin{array}{l}\text { Name of the } \\
\text { Communities } \\
\text { Mahato }\end{array}$} & \multirow{3}{*}{$\begin{array}{l}\text { Total } \\
\text { Popu } \\
156 \\
\end{array}$} & \multirow{2}{*}{\multicolumn{4}{|c|}{$\begin{array}{l}\text { Children 11-14yrs age } \\
\text { Male T\% Female T\% }\end{array}$}} & \multicolumn{4}{|c|}{ Adult $15-50$ yrs age } & \multirow{2}{*}{\multicolumn{4}{|c|}{$\frac{\text { Aged above } 60 \text { yrs }}{\text { Male T\% Female T\% }}$}} \\
\hline & & & & & & & \multicolumn{2}{|c|}{ Male T\% } & \multicolumn{2}{|c|}{$\begin{array}{l}\text { Female } \\
\mathrm{T} \%\end{array}$} & & & & \\
\hline & & & 29 & 18.59 & 15 & 09.62 & 37 & 23.78 & 29 & 18.59 & 19 & 12.18 & 27 & 17.35 \\
\hline 02 & Mahali & 58 & 07 & 12.06 & 08 & 13.79 & 12 & 20.68 & 10 & 17.24 & 09 & 15.51 & 12 & 20.68 \\
\hline 03 & Total & 214 & 36 & 16.82 & 23 & 10.74 & 49 & 22.89 & 39 & 18.22 & 28 & 13.08 & 39 & 18.22 \\
\hline
\end{tabular}

The table 1 shows the population distribution of the village Keuindisole where Mahali and Mahato are living together. Total population of Mahali is 58 and Mahato 156. The total village population is identified as 214. Hence it depicts $27.10 \%$ of Mahali and $72.90 \%$ are Mahato. 
International Advanced Research Journal in Science, Engineering and Technology

Vol. 8, Issue 6, June 2021

DOI: $10.17148 /$ IARJSET.2021.86107

Table 2. Family Size of the Selected Tribes

\begin{tabular}{|l|l|l|l|l|l|}
\hline SN & $\begin{array}{l}\text { Name of the } \\
\text { selected } \\
\text { Communities }\end{array}$ & $\begin{array}{l}\text { Total no of } \\
\text { Household }\end{array}$ & $\begin{array}{l}\text { Small Family size } \\
\text { (Members up to 4 } \\
\text { persons) }\end{array}$ & $\begin{array}{l}\text { Medium Family } \\
\text { Size (Members 5-10 } \\
\text { persons) }\end{array}$ & $\begin{array}{l}\text { Large Family Size } \\
\text { (Members more than } \\
10 \text { persons) }\end{array}$ \\
\hline & & Total \% & Total \% & Total \% & Total \% \\
\hline 01 & Mahato & $2873.68 \%$ & $0517.85 \%$ & $1657.14 \%$ & $0725 \%$ \\
\hline 02 & Mahali & $1026.31 \%$ & $0220 \%$ & $0770 \%$ & $0110 \%$ \\
\hline 03 & Total & $38100 \%$ & $0718.42 \%$ & $2360.52 \%$ & $0821.05 \%$ \\
\hline
\end{tabular}

The table 2 points out family size of the Mahali and Mahato too. $20 \%$ is showing SFS means small family size, $70 \%$ MFS which denotes medium family size and $10 \%$ large family size denotes LFS. Most of the Mahali population is in medium family size group.

Table 3. Degree of Dependence on the Forest for Collections of Non-Timber of Minor Forest Produces

\begin{tabular}{|l|l|l|l|l|l|}
\hline SN & $\begin{array}{l}\text { Name of the } \\
\text { Selected } \\
\text { Communities }\end{array}$ & $\begin{array}{l}\text { Total No of } \\
\text { Population }\end{array}$ & $\begin{array}{l}\text { Regular } \\
\text { Dependence }\end{array}$ & $\begin{array}{l}\text { Occasional } \\
\text { Dependence }\end{array}$ & $\begin{array}{l}\text { Non- } \\
\text { Dependence }\end{array}$ \\
\hline & & & Total \% & Total \% & Total \% \\
\hline 01 & Mahato & 156 & $4026 \%$ & $3523 \%$ & $8151 \%$ \\
\hline 02 & Mahali & 58 & $1831 \%$ & $1017 \%$ & $3052 \%$ \\
\hline 03 & Total & 214 & $5827 \%$ & $4521 \%$ & $11152 \%$ \\
\hline
\end{tabular}

Degree of dependence on the forest for collections of non-timber minor forest produces the Mahali are showing $31 \%$ regular dependence, $17 \%$ occasional dependence and 52\% non-dependence. Hence $48 \%$ dependence and $52 \%$ nondependence which counts $4 \%$ deviation between dependence and non-dependence.

Table 4 Basket Making and Market Economy

\begin{tabular}{|l|l|l|l|l|l|l|l|}
\hline $\begin{array}{l}\text { S1 } \\
\text { no }\end{array}$ & $\begin{array}{l}\text { Name of the } \\
\text { Products }\end{array}$ & $\begin{array}{l}\text { Required } \\
\text { Raw } \\
\text { Materials } \\
\text { Manufactured }\end{array}$ & $\begin{array}{l}\text { Total no of } \\
\text { Items } \\
\text { Cost }\end{array}$ & $\begin{array}{l}\text { Selling Price } \\
\text { to the Market }\end{array}$ & $\begin{array}{l}\text { Income- } \\
\text { Expen- } \\
\text { Diture ratio }\end{array}$ & $\begin{array}{l}\text { Man power } \\
\text { involve }\end{array}$ \\
\hline 01 & Basket & 01 & 07 & 100 & 350 & 250 & $\begin{array}{l}3 \text { days } \\
=6 \times 3=18 \\
\text { hours }\end{array}$ \\
\hline 02 & Kulla & 01 & 12 & 100 & 480 & 380 & $\begin{array}{l}3 \text { days } \\
=3 \times 3=9 \\
\text { hours }\end{array}$ \\
\hline 03 & Mat & 01 & 03 & 100 & 600 & 500 & $\begin{array}{l}3 \text { days } \\
=7 \times 3= \\
21 \text { hours }\end{array}$ \\
\hline 04 & 03 & & & & & 1430 & 1130 \\
4
\end{tabular}

The table 4 denotes the exact scenario of the village Keundesole. Involvement of a single person for making Bamboo items from a single Bamboo, exhibits market economy and the production thereof, along with man power estimation. It has been observed that, total three items made form a single piece of Bamboo is needed 48-man hours in 3 days i.e., 12 hours per day. Rs1130 total income from 300 Rs. Investment. Per day per person income= Rs 376.67 and per person per working hour income $=$ Rs 23.55 of total 48 working hours. Thereby, market economy from the bamboo products have demand at present day which enhance socio-economic upgradation in the Mahali tribal society. 
International Advanced Research Journal in Science, Engineering and Technology

Vol. 8, Issue 6, June 2021

DOI: $10.17148 /$ IARJSET.2021.86107

Table 5: Pie Diagram of Forest Dependence

\section{Degree of Forest Dependence}

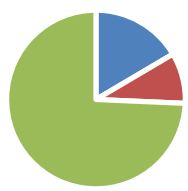

- 1st Qtr $\quad$ 2nd Qtr $\quad$ - 3rd Qtr

The pie diagram shows $1^{\text {st }}$ qtr $17 \%$ regular dependence, $2^{\text {nd }}$ qtr depicts $9 \%$ occasional dependence and $3^{\text {rd }}$ qtr denotes $74 \%$ non-dependence. Though degree of dependence is deteriorating gradually still their forest dependence only $26 \%$ remaining for livelihood sustenance and traditional wellbeing for sustainability. Market economy is maintaining for their craftsmanship and identification for the same. While competition law also hindrances the actual wellbeing as a craftsman tribe along with market economy.

\section{Table 6 Income-Expenditure Relationship}

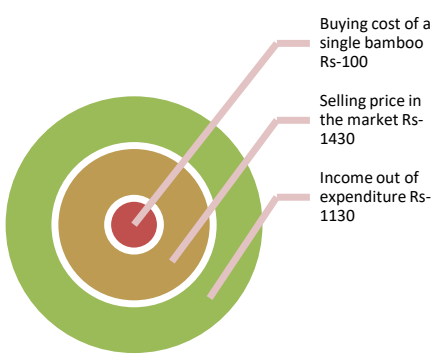

Table 6 proves the relationship of income-expenditure. If buying cost of the raw materials is hundred rupees per piece. A person can earn eleven hundred thirty rupees per bamboo with selling price of one thousand four hundred thirty from a single bamboo. It can be identified as in a circle when buying cost is in the centre as a nucleus then market price and income out of expenditure points out proton and neutron.

Table 7 Income expenditure histogram

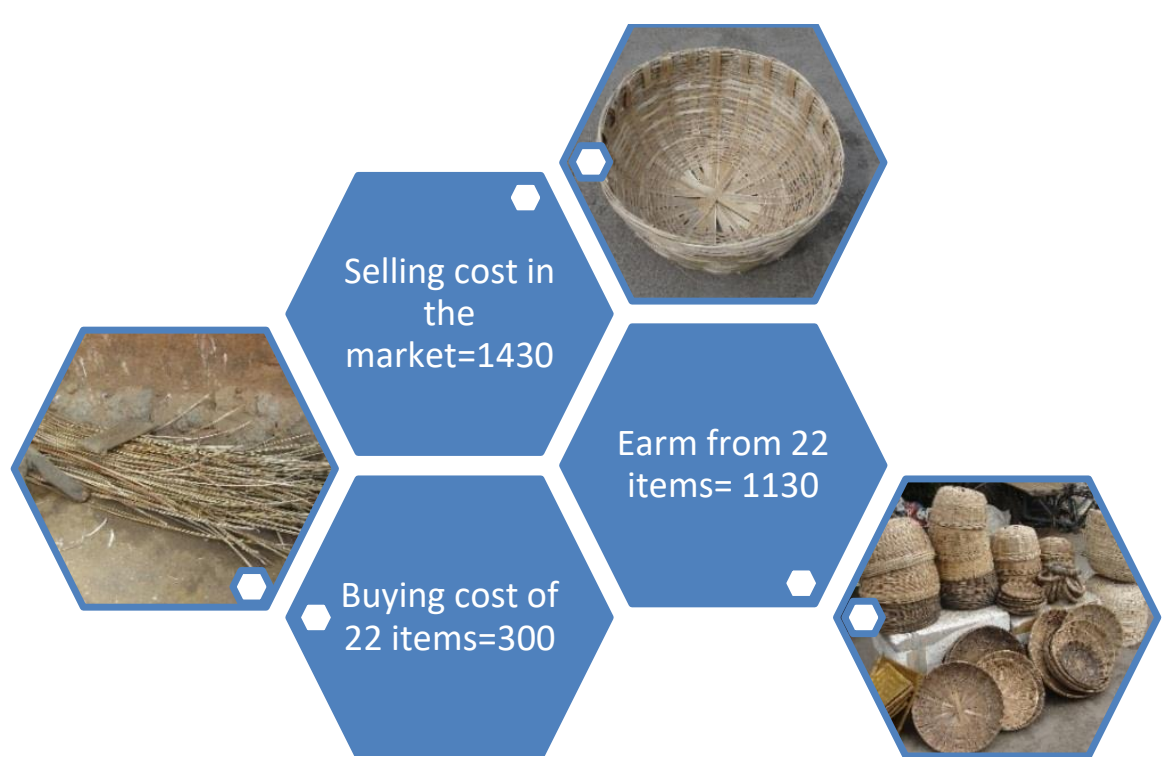




\section{International Advanced Research Journal in Science, Engineering and Technology}

Vol. 8, Issue 6, June 2021

\section{DOI: 10.17148/IARJSET.2021.86107}

The histogram shows the income -expenditure ratio of 22 items manufactured from 3 pieces of bamboo. Buying cost 300 rupees, selling price in the market is 1430 rupees while income depicts rupees 1130 from 22 items. Hence histogram establishes the perfect relationship between buying, selling and earning nomenclature of the bamboo products of the Mahali and their status of market economy while competition law perpetuates its consortium.

\section{CONCLUSION}

Market economy is relied upon supply and demand which dictates how goods and services are manufactured or produced. This allows businesses and individuals to seek out goods and services of the highest possible quality for the lowest possible price while competition laws conjugate the duo. Competitive markets give consumers wider choice and lower prices. It gives sellers stronger incentives and platform orientation to minimize their costs through innovation and other productivity enhancing techniques, also exploration of technologies. This enables firms to pass on cost savings to the customers and offer better products and greater choice at lower prices. Competition law is eventually concerned with the study of market economy, the objective being to ensure that there is competition between the suppliers in any market and that the competition benefits consumers. The present study also explores in the market economy at the same time competition law orientation. There are several caste peasants who are practising the same market economy, manufacturing bamboo products buying bamboo as raw materials enhance competition with in the same infrastructure. Hence the present sequel was emphasized on the present socio-economic conditions and sustenance of livelihood under the implemented Forest Act, Policies along with economics of competition law orientation in the form of a market economy and its consequences on the forest dwelling craftsman tribe the Mahali, exhibits juxtaposition of their ware in the market economy and competition thereof, enhance development in the economic pursuit with protection of crafts from imperil.

\section{REFERENCES}

1. Adhikary Ashim, 1990. Socio-economic Conditions of the Mahali, Published from CRI, Kolkata

2. Ahmad A .I .Shajrawi; Nawab Ali Khan. "International Marketing in the Modern Era". International Research Journal on Advanced Science Hub, 2, Special Issue ICAET 11S, 2020, 16-19.

3. Pooja Dahiya; Roopsi Kaushik; Anil Sindhu. "Physiological Analysis of Dairy Effluent". International Research Journal on Advanced Science Hub, 2, Special Issue ICAET 11S, 2020, 20-29.

4. AnupamVerma; Vandana Srivastava. "Natural Resource Consumption and Lockdown". International Research Journal on Advanced Science Hub, 2, 6, 2020, 79-86. doi: 10.47392/irjash.2020.41

5. Chetan K; YogishS.N.. "Global Economy with comparative study of India and China in a pandemic situation". International Research Journal on Advanced Science Hub, 2, Special Issue ICAMET 10S, 2020, 1-5. doi: 10.47392/irjash.2020.190

6. MoasunepKichu; Manali Bhattacharya. "Stingless Honey a Sustainable Economy in Nagaland". International Research Journal on Advanced Science Hub, 2, Special Issue ICARD, 2020, 231-235. doi: 10.47392/irjash.2020.125

7. Baskey, D.N 2008 . The Mahali Economy Inter India Publication N.Delhi

8. Gupta, Akriti 2020. The Competition Law in India: An Overview, in The Legal Bites.

9. Sachs Jeffrey 2011. The Price of Civilization Random Press US.

10. Sachs Jeffery 1993. Poland's Jump to the Market Economy Published from Poland. 